\title{
A comparative study of heavy metal accumulation and antioxidant responses in Vaccinium myrtillus L. leaves in polluted and non-polluted areas
}

\author{
Marta Kandziora-Ciupa • Ryszard Ciepal • \\ Aleksandra Nadgórska-Socha • \\ Gabriela Barczyk
}

Received: 13 August 2012 / Accepted: 28 December 2012/Published online: 15 January 2013

(C) The Author(s) 2013. This article is published with open access at Springerlink.com

\begin{abstract}
The purpose of this study was to explore a possible relationship between the availability of metals in soil $(\mathrm{Cd}, \mathrm{Fe}, \mathrm{Mn}, \mathrm{Pb}$ and $\mathrm{Zn})$ and their concentrations in leaves of Vaccinium myrtillus $\mathrm{L}$. as a species which has been reported to be a successful colonist of acid-and-heavy metal-contaminated soil. Analysis also concerned the antioxidant response of plants from three heavily polluted (immediate vicinity of: zinc smelter, iron smelter and power plant) and three relatively clean sites (nature reserve, ecological site and unprotected natural forest community) in southern Poland. The contents of glutathione, non-protein thiols, protein, proline and activity of guaiacol peroxidase in leaves of bilberry were measured. Generally, the concentrations of metals in the $\mathrm{HNO}_{3}$ and $\mathrm{CaCl}_{2}$ extracants of the soil from the polluted sites were higher. Moreover, the antioxidant responses were also elevated in bilberries in the polluted sites. Significant positive relationships between $\mathrm{Cd}, \mathrm{Pb}$ and $\mathrm{Zn}$ concentrations in soil and in the plants were found. In the leaves of $V$. myrtillus from the polluted sites, higher concentrations of $\mathrm{Cd}, \mathrm{Pb}$ and $\mathrm{Zn}$ were noted (In Miasteczko Śląskie respectively $6.26,157.09$ and $207.17 \mathrm{mgkg}^{-1}$ d.w.). We found a positive correlation between the increase in the NPTs and protein contents as well as the $\mathrm{Cd}, \mathrm{Pb}$ and $\mathrm{Zn}$ concentrations in V. myrtillus. $\mathrm{Cd}, \mathrm{Pb}$ and $\mathrm{Zn}$ also decreased guaiacol peroxidase activity. However, the activity of this enzyme increased under Fe. A decreasing trend in glutathione contents was observed with increasing iron and
\end{abstract}

Responsible editor: Elena Maestri

M. Kandziora-Ciupa $(\bowtie) \cdot R$. Ciepał · A. Nadgórska-Socha • G. Barczyk

Department of Ecology, University of Silesia, Bankowa 9,

PL 40-007 Katowice, Poland

e-mail: marta.kandziora-ciupa@us.edu.pl manganese concentrations in bilberry leaves. Parameters such as protein, non-protein - $\mathrm{SH}$ groups and changes in GPX activity seem to be universal, sensitive and correlated well with heavy metal stress.

Keywords Antioxidant response $\cdot$ Heavy metal $\cdot$ Vaccinium myrtillus
Abbreviations
NPTs Non-protein thiols
GSHt Glutathione total
GPX Guaiacol peroxidase

\section{Introduction}

Vaccinium myrtillus L. (bilberry) is a dwarf deciduous shrub which dominates plant life forms in the herbaceous layer of pine forests in temperate climates (Białońska et al. 2007; Martz et al. 2010). It is known to play an important role in natural succession and in regulating the nutrient fluxes of forest ecosystems and thus in their productivity (Mróz and Demczuk 2010). Bilberry possesses a relatively high resistance to pollution, and it has been reported to be a successful colonist of acid-and-heavy metal-contaminated soils (Uhlig and Junttila 2001; Mróz and Demczuk 2010). In view of this fact, $V$. myrtillus L. is common both in unpolluted and polluted habitats. The accumulation of elements in its foliage has been widely used in environmental monitoring (Reimann at al. 2001; Salemaa et al. 2004; Brekken and Steinnes 2004; Białońska et al. 2007).

Heavy metals are highly toxic to plants. Their uptake and accumulation by plant tissues cause various morphological, 
physiological and biochemical responses (Doganlar and Atmaca 2011). Some metal ions are likely to remain in the cytoplasm and induce oxidative stress via generation of reactive oxygen species (ROS) such as hydrogen peroxide $\left(\mathrm{H}_{2} \mathrm{O}_{2}\right)$, superoxide and hydroxyl radicals which hinder cell metabolism and lead to multiple toxic effects like lipid peroxidation, protein cleavage or DNA damages (Prasad 1999; Unyayar et al. 2006; Dazy et al. 2008; Pongrac et al. 2009). Once formed, ROS must be detoxified as efficiently as possible to minimize damage. Antioxidant systems in plants are complex and involve an array of non-enzymatic and enzymatic mechanisms capable of preventing the cascades of uncontrolled oxidation (Gratão et al. 2005, 2008).

Glutathione is one of the crucial plant metabolites in terms of intracellular defense against ROS-induced oxidative damage (Gill and Tuteja 2010). Glutathione creates complexes with heavy metals, and an induction of glutathione as well as cysteine synthesis has been documented in plants as a response to heavy metal stress. The changes in glutathione total (GSHt) level are dependent on the metal treatment and the part of plant (Arya et al. 2008; Nadgórska-Socha et al. 2012). Glutathione (GSH) is also the predominant non-protein thiol, redox buffer, phytochelatin precursor and substrate for keeping the ascorbate in reduced form in the ascorbate glutathione pathway (Demirevska-Kepova et al. 2004). Nonprotein compounds rich in -SH groups (e.g. phytochelatins) are involved in metal detoxification and/or metal allocation between different organs of the plant because their main task is binding of metal ions and forming non-toxic complexes with a metal which are transported from the cytoplasm into the vacuole (Andrade et al. 2010; Yadav 2010).

Among amino acids, proline has been shown to have an important role (Sharma and Dietz 2006). Metal-induced proline accumulation has been observed, and it has been suggested that this amino acid acts as a radical scavenger, or it is involved in metal ion chelation (Andrade et al. 2009). In plants, proline constitutes $<5 \%$ of the total pool of free amino acids under normal conditions and represents $80 \%$ of total amino acid pool under stress (Kumar et al. 2010).

Peroxidases are antioxidant enzymes which are significant in plant growth and development. Activities of these enzymes are changed under both biotic and abiotic stress conditions and are used as a potential indicator of metal toxicity (Radotić et al. 2000; Macfarlane and Burchett 2001; Baycu et al. 2006; Doganlar and Atmaca 2011).

Antioxidant systems in plants may be used as early indicators of environmental stress on a target organism before morphological or ultrastructural damage occurs. Moreover, they can also be used as warning indicators of the surrounding ecosystem (Białońska et al. 2007).

The objectives of the present study were to establish the concentrations of heavy metals as well as to determine and compare the levels of antioxidants (non-protein thiols, glutathione and proline), antioxidant enzyme (guaiacol peroxidase) and proteins content in leaves of $V$. myrtillus L. growing naturally at polluted and potentially unpolluted areas. We also studied the potential availability of metals $(\mathrm{Cd}, \mathrm{Pb}, \mathrm{Zn}, \mathrm{Fe}$ and $\mathrm{Mn})$ in the soil originating from the same sites. Comparing analytical results of the heavy metals and ecophsyological changes in bilberry leaves, the following questions will be investigated:

1. Do investigated physiological parameters in bilberry plants from the polluted sites vary from the ones collected at non-contaminated sites?

2. Do ecophysiological parameters are good indicators of stress caused by heavy metals in plants living in field conditions?

\section{Material and methods}

Study area

The study was performed in typical pine forests located in three heavily polluted (immediate vicinity of: the zinc smelter, iron smelter and power plant) and three relatively clean sites (nature reserve, ecological site and unprotected natural forest community). All of the sites were situated in southern parts of Poland in the Ślaskie or Małopolskie provinces (Table 1 and Fig. 1).

\section{Sample collection}

Consideration of seasonal variations is essential during biomonitoring programs (Oliva et al. 2012). Metal accumulation may depend on seasonal variation. Some publications report the highest foliar levels in spring and the lowest during winter, whereas others have indicated the highest metal contents during autumn and relatively low levels during spring (Martin and Couphtrey 1982; Kim and Fergusson 1994; Brekken and Steinnes 2004; Baycu et al. 2006; Deram et al. 2006). Use of biomarkers, such as our antioxidants in biomonitoring studies, is often complicated because levels of chemical pollutants in the environment often display wide seasonal variation in response to climate and other factors. That is why we decided to sample the material three times in order to minimize the effect of seasonal factors and show changes in antioxidant response induced by heavy metals during a growing season including the most important periods of the bilberry growth (flowering stage, fructification and end of growing season).

V. myrtillus L. leaves and soil samples were collected in May, July and September of 2009. Each sampling site consisted of $25 \times 25-\mathrm{m}$ squares within which leaf and soil samples were randomly collected. The fully matured, undamaged leaves were detached from at least 20 different shrubs and 
Table 1 Site description

\begin{tabular}{|c|c|c|c|c|}
\hline $\begin{array}{l}\text { Sampling } \\
\text { site no. }\end{array}$ & Sites & Latitude & Longitude & $\begin{array}{l}\text { Selected soil parameters (Kandziora-Ciupa } \\
\text { unpublished data) }\end{array}$ \\
\hline \multicolumn{5}{|l|}{ Polluted } \\
\hline M1 & $\begin{array}{l}\text { Nearest vicinity of zinc smelter } \\
\text { "Miasteczko Śląskie" in Miasteczko } \\
\text { Śląskie (activities since 1968) }\end{array}$ & $50^{\circ} 31^{\prime} 22.655^{\prime \prime} \mathrm{N}$ & $18^{\circ} 56^{\prime} 8.699^{\prime \prime} \mathrm{E}$ & $\begin{array}{l}\text { The contents of organic matter and } \mathrm{C} / \mathrm{N} \text { ratio are the } \\
\text { lowest among all the sites, } 7.10 \% \text { and } 12.43 \text {, } \\
\text { respectively. The } \mathrm{pH} \text { is } \sim 4.45 ; \mathrm{Ca}, 346.34 \mathrm{mgkg}^{-1} \text {; } \\
\mathrm{Mg}, 32.33 \mathrm{mgkg}^{-1} \text {. }\end{array}$ \\
\hline L2 & $\begin{array}{l}\text { Nearest vicinity of iron smelter } \\
\text { "ArcelorMittal Poland S.A." in } \\
\text { Dąbrowa Górnicza-Łosień (activities } \\
\text { since 1976) }\end{array}$ & $50^{\circ} 22^{\prime} 0.768^{\prime \prime} \mathrm{N}$ & $19^{\circ} 19^{\prime} 22.979^{\prime \prime} \mathrm{E}$ & $\begin{array}{l}\text { The soil is richer in } \mathrm{Ca} \text { and } \mathrm{Mg} \text {, and } \mathrm{pH} \text { is the highest } \\
\text { compared with other sites }\left(\mathrm{Ca}, 3,166.17 \mathrm{mgkg}^{-1} \text {, }\right. \\
\left.\mathrm{Mg}, 165.88 \mathrm{mgk}^{-1}, \mathrm{pH} \sim 4.97\right) \text {. }\end{array}$ \\
\hline $\mathrm{J} 3$ & $\begin{array}{l}\text { Nearest vicinity of power plant } \\
\text { "Jaworzno III" in Jaworzno (activities } \\
\text { since 1979) }\end{array}$ & $50^{\circ} 12^{\prime} 14.111^{\prime \prime} \mathrm{N}$ & $19^{\circ} 11^{\prime} 51.792^{\prime \prime} \mathrm{E}$ & $\begin{array}{l}\mathrm{pH} \sim 4.30 ; \text { organic matter, } 26.48 \% \text {; C/N, 19.59; Ca, } \\
2,552.34 \mathrm{mgkg}^{-1} ; \mathrm{Mg}, 110.59 \mathrm{mgkg}^{-1} \text {. }\end{array}$ \\
\hline \multicolumn{5}{|c|}{ Unpolluted } \\
\hline $\mathrm{P} 4$ & $\begin{array}{l}\text { Nature reserve "Pazurek" in Jaroszowiec } \\
\text { Olkuski }\end{array}$ & $50^{\circ} 19^{\prime} 59^{\prime \prime} \mathrm{N}$ & $19^{\circ} 37^{\prime} 24^{\prime \prime} \mathrm{E}$ & $\begin{array}{l}\text { The concentration of } \mathrm{Mg} \text { is lowest among all sites- } \\
25.47 \mathrm{mgkg}^{-1} \cdot \mathrm{pH} \sim 3.67 \text {; organic matter, } 15.75 \% \text {; } \\
\mathrm{C} / \mathrm{N}, 17.24 ; \mathrm{Ca}, 587.62 \mathrm{mgkg}^{-1} \text {. }\end{array}$ \\
\hline PB5 & $\begin{array}{l}\text { Ecological site "Płone Bagno" in } \\
\text { Katowice }\end{array}$ & $50^{\circ} 10^{\prime} 07^{\prime \prime} \mathrm{N}$ & $19^{\circ} 05^{\prime} 18^{\prime \prime} \mathrm{E}$ & $\begin{array}{l}\text { The organic matter content and } \mathrm{C} / \mathrm{N} \text { ratio are the } \\
\text { highest compared with other sites }(36.54 \% \text { and } \\
20.59 \text {, respectively). } \mathrm{pH} \sim 3.46 ; \mathrm{Ca}, 443.30 \mathrm{mg} \\
\mathrm{kg}^{-1} ; \mathrm{Mg}, 65.94 \mathrm{mgg}^{-1} \text {. }\end{array}$ \\
\hline K6 & $\begin{array}{l}\text { Unprotected natural forest community } \\
\text { in Kobiór }\end{array}$ & $50^{\circ} 4^{\prime} 22.08^{\prime \prime} \mathrm{N}$ & $18^{\circ} 56^{\prime} 16.656^{\prime \prime} \mathrm{E}$ & $\begin{array}{l}\text { The } \mathrm{pH}(3.45) \text { of the soil and concentration of } \mathrm{Ca} \\
\left(308.82 \mathrm{mgkg}^{-1}\right) \text { are the lowest among all sites. } \\
\text { Organic matter, } 22.26 \% ; \mathrm{C} / \mathrm{N}, 16.86 ; \mathrm{Mg}, 50.91 \\
\mathrm{mgkg}^{-1} \text { ) }\end{array}$ \\
\hline
\end{tabular}

pooled into one sample per site. After collection, samples were covered with plastic bags, deposited in ice, immediately transported to the laboratory and then frozen until analysis.
Soil sample were taken in the neighbourhood of the samples shrubs from a depth of $0-10 \mathrm{~cm}$. At each site, soil sub-samples were combined in a composite sample.
Fig. 1 Location map of sampling sites

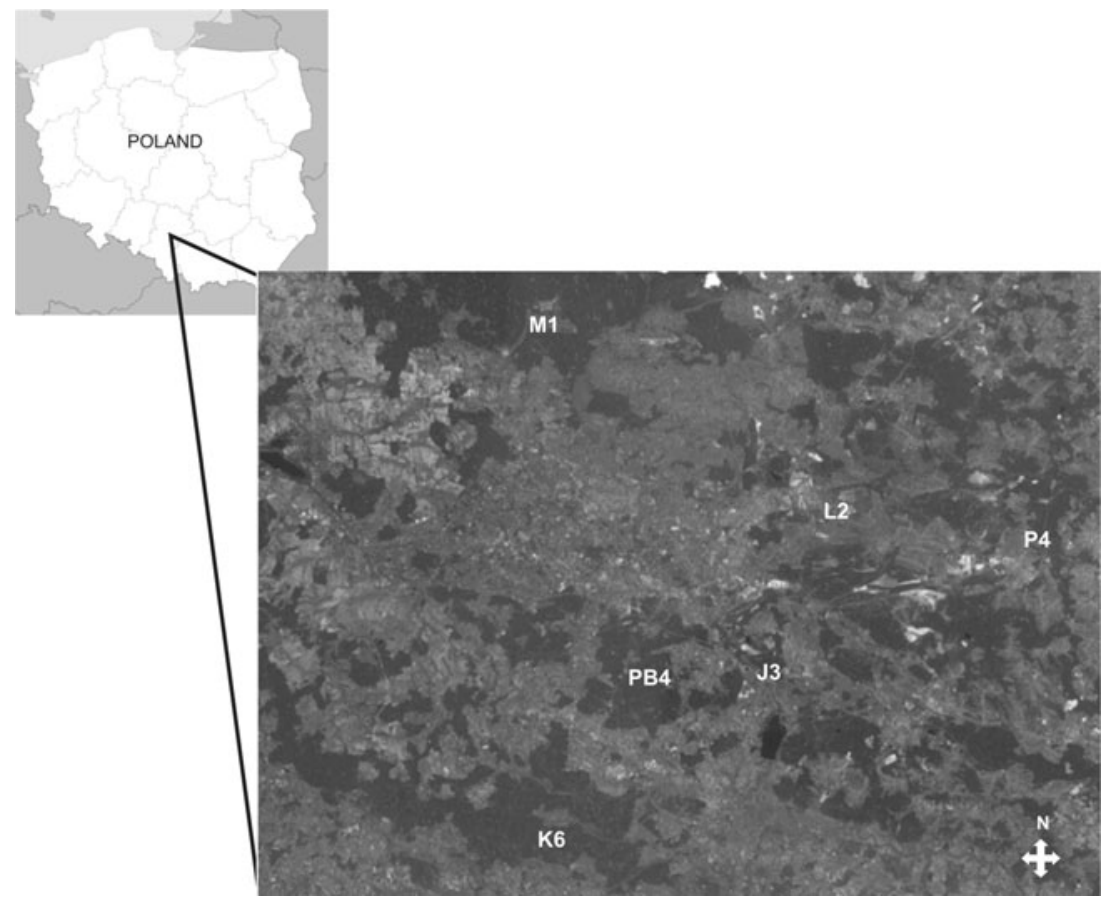


Analysis of metal concentration in the soil and samples of plants

The concentrations of $\mathrm{Cd}, \mathrm{Pb}, \mathrm{Zn}, \mathrm{Fe}$ and $\mathrm{Mn}$ were analysed in particular soil fractions and in the leaves of $V$. myrtillus L. The metal content in soil was estimated according to the method of Bouwmann et al. (2001) and Ostrowska et al. (1991) in the air-dried soil samples, which were sieved through a $1-\mathrm{mm}$ sieve. Metals were extracted from soil with $0.01 \mathrm{M} \mathrm{CaCl}_{2}$ (potentially bioavailable elements) or with $2 \mathrm{M} \mathrm{HNO}_{3}$ (acid extracted elements). For the $\mathrm{CaCl}_{2}$ extraction, $5 \mathrm{~g}$ of soil with $50 \mathrm{ml}$ of $0.01 \mathrm{M} \mathrm{CaCl}_{2}$ solution was mechanically shaken for $5 \mathrm{~h}$. The $\mathrm{HNO}_{3}$-extractable fraction was obtained by shaking $10 \mathrm{~g}$ of soil sample with $100 \mathrm{ml}$ of $2 \mathrm{M} \mathrm{HNO}_{3}$ for $1 \mathrm{~h}$. The content of metals was measured in the filtered extracts by inductively coupled plasma-atomic emission spectroscopy (Spectro Analytical Instruments).

In order to determine the heavy metal concentrations in the leaves of bilberry, plant material was washed in a tap with distilled water and dried at $105^{\circ} \mathrm{C}$. A $0.25-\mathrm{g}$ portion of dried plant material was treated with $5 \mathrm{ml}$ of concentrated nitric acid and left for $24 \mathrm{~h}$. Next, the samples were digested at $110^{\circ} \mathrm{C}$ until complete mineralization was achieved. After mineralization, the samples were diluted with deionized water to a volume of $10 \mathrm{ml}$. Concentration of $\mathrm{Cd}, \mathrm{Pb}, \mathrm{Zn}, \mathrm{Fe}$ and $\mathrm{Mn}$ was measured using inductively coupled plasma-atomic emission spectroscopy (Spectro Analytical Instruments). The quality of the analytical procedure was checked using a reference material (certified reference material CTA-OTL-1 Oriental Tobacco Leaves) with the same quantities of samples.

Analysis of the biochemical parameters of the plants

Protein content was determined according to the method of Bradford (1976) using bovine serum albumin as a standard. Proline content was determined by the method of Bates et al. (1973). The plant material (0.5 g) was homogenized in $10 \mathrm{ml}$ of sulfosalicylic acid (3 g per $100 \mathrm{ml}$ ), and the homogenate was filtered through Whatman No. 2 filter paper. The reaction mixture containing $2 \mathrm{ml}$ of homogenate, $2 \mathrm{ml}$ acid ninhydrin and $2 \mathrm{ml}$ of glacial acetic acid was incubated at $100{ }^{\circ} \mathrm{C}$ for $1 \mathrm{~h}$. The reaction mixture was placed on ice and extracted with $4 \mathrm{ml}$ of toluene. The absorbance was read at $520 \mathrm{~nm}$ using toluene as the blank. The proline content was expressed in micromoles proline per gram of fresh weight.

To measure the GSHt concentration, plant parts $(0.5 \mathrm{~g})$ were homogenized in trichloroacetic acid $(5 \mathrm{~g}$ per $100 \mathrm{ml})$ and $0.125 \mathrm{mM}$ phosphate buffer $(\mathrm{pH} 6.3)$ with $6.3 \mathrm{mM}$ ethylenediaminetetraacetic acid (EDTA) and were centrifuged at $10,000 \times g$ for $10 \mathrm{~min}$ at $4{ }^{\circ} \mathrm{C}$. Supernatants were used for GSH determination using the DTNB-GSSG reductase recycling procedure according to Anderson (1985). The reaction mixture contained $0.2 \mathrm{ml}$ of supernatant, $0.6 \mathrm{ml}$ of
$0.3 \mathrm{mM}$ NADPH, $0.1 \mathrm{ml}$ of $6 \mathrm{mM}$ DTNB and $0.1 \mathrm{ml}(0.5 \mathrm{IU}$ $\mathrm{ml}^{-1}$ ) of glutathione reductase. The linear changes in the absorbance of the reaction mixtures were measured at $412 \mathrm{~nm}$, and the GSHt was expressed as micromoles GSH per gram fresh weight.

The content of non-protein thiols was estimated as described by Mass et al. (1987). The plant material was homogenized in a $5 \mathrm{vol} / \mathrm{g}$ mixture containing 5-sulphosalicylic acid (2 g per $100 \mathrm{ml})$ and $1 \mathrm{mM}$ EDTA and sodium ascorbate $(0.15 \mathrm{~g}$ per $100 \mathrm{ml}$ ). The samples were centrifuged at $20,000 \times \mathrm{g}$ for $10 \mathrm{~min}$ at $4{ }^{\circ} \mathrm{C}$. Then, a $0.5-\mathrm{ml}$ liquid supernatant, $0.5 \mathrm{ml}$ of a $1 \mathrm{M}$ sodium phosphate buffer ( $\mathrm{pH} 8.0$ ) and $100 \mu \mathrm{l}$ of $10 \mathrm{mM} \mathrm{5,5^{ \prime } -}$ dithio-bis (2-nitrobenzoic acid) (DTNB) were put into test tubes. The absorbance at $415 \mathrm{~nm}$ was read $1 \mathrm{~min}$ after the addition of DTNB. The number of non-protein SH groups was established based on a curve prepared using L-cysteine and expressed as nanomoles - SH per gram fresh weight.

For the analysis of guaiacol peroxidase, fresh plant material was homogenized in a $100-\mathrm{mM}$ phosphate buffer ( $\mathrm{pH}$ 6.8). The guaiacol peroxidase (GPX) activity was measured at $470 \mathrm{~nm}$ according to Fang and Kao (2000) and Liu et al. (2004) with guaiacol as the substrate. The GPX activity was measured in a reaction mixture $(3 \mathrm{ml})$ containing a $50 \mathrm{mM}$ phosphate buffer $(\mathrm{pH} 5.8), 1.6 \mu \mathrm{l} \mathrm{H}_{2} \mathrm{O}_{2}, 1.5 \mu \mathrm{l}$ guaiacol and $0.2 \mathrm{ml}$ enzyme extract. The activity was calculated using the extinction coefficient $\left(26 \mathrm{mM}^{-1} \mathrm{~cm}^{-1}\right)$ for tetraguaiacol and was expressed in micromoles tetraguaiacol per gram fresh weight per minute.

\section{Statistical analysis}

The data concerning the biochemical parameters and metal content were analysed, checked for normality and equality of variance. The data were analysed by ANOVA, and the treatments were treated as the independent variables. Significant statistical differences of all variables were established using the Tukey's test (ANOVA; Statistica 10 package). We also calculated the Pearson's correlation coefficient between the metal concentrations in separate soil extracants and in the leaves of $V$. myrtillus, and between the metal concentrations and biochemical parameters in the bilberry leaves. CANOCO 4.5 was used to carry out principal component analysis (PCA) which assessed the similarities and relations between heavy metal concentrations and biochemical parameters in the leaves of $V$. myrtillus in the studied areas.

\section{Results}

Heavy metal content and their availability in soil

There were significant differences in the content of the metals studied $\left(\mathrm{HNO}_{3}\right.$ extracted and $\mathrm{CaCl}_{2}$ extracted) 
between the polluted and potentially clean sites (Tables 2 and 3). Additionally, there was a clear difference in the concentrations of metals between the fraction of soil extracted with $\mathrm{HNO}_{3}$ and the fraction extracted with $\mathrm{CaCl}_{2}$. Among the metals examined, the highest concentrations of $\mathrm{Fe}, \mathrm{Pb}$ and $\mathrm{Zn}$ were measured in the acid-extracted soil fraction. A several times lower concentration of the metals examined was determined in the fraction of soil extracted with $\mathrm{CaCl}_{2}$. The following descending order of bioavailability was found among the heavy metals: $\mathrm{Mn}>\mathrm{Zn}>\mathrm{Cd}>\mathrm{Pb}>\mathrm{Fe}$.

Heavy metal concentration in plants

The mean values of heavy metal concentrations in $V$. myrtillus leaves were found in descending order: $\mathrm{Mn}>\mathrm{Fe}>\mathrm{Zn}>\mathrm{Pb}>\mathrm{Cd}$. There was a clear increase in the concentration of the metals studied in leaves of $V$. myrtillus at polluted sites. The exception was Mn, with the highest content observed at P4, PB5 and K6 sites. In most cases, metal content in $V$. myrtillus leaves increased with each month of sampling (Table 4). We found a strong positive correlation between concentrations of $\mathrm{Cd}, \mathrm{Pb}$ and $\mathrm{Zn}$ in separate soil extracants and in leaves of bilberry. The range of coefficients was $0.61-0.89$ with $p<0.05$. There was no correlation between the $\mathrm{Fe}$ and $\mathrm{Mn}$ concentrations in leaves and $\mathrm{Fe}$ and $\mathrm{Mn}$ concentrations measured in either of the two extractants (Table 5).

The biochemical status of the plants

At most sites, the total content of glutathione was by far the highest in May. The highest accumulation GSHt was found in V. myrtillus leaves from the M1 site-236.84 $\mu \mathrm{mol} \mathrm{GSHt}$ $\mathrm{g}^{-1}$ fresh weight (Fig. 2). There were no clear differences in glutathione content between contaminated and potentially non-contaminated sites. In addition, there was a negative correlation between the GSHt content and the concentration of Fe and $\mathrm{Mn}$ in the leaves of $V$. myrtillus (Table 6).

The greatest concentration of non-protein-SH groups in the leaves of $V$. myrtillus during the entire growing season was observed in the most contaminated M1 site $(1,497.33$ $1,800 \mathrm{nmol}-\mathrm{SH} \mathrm{g}^{-1}$ fresh weight) (Fig. 3). This dependence was confirmed by a positive correlation between nonprotein $-\mathrm{SH}$ groups and the content of $\mathrm{Cd}, \mathrm{Pb}$ and $\mathrm{Zn}$ in the leaves of bilberry (Table 6). At the other sites, the content of non-protein thiols (NPTs) was the lowest in May and the highest in July. As with the NPTs, the highest protein content was also noted at the M1 site $\left(4.28 \mathrm{mgg}^{-1}\right.$ fresh weight; Fig. 4). A significant positive correlation between protein content and concentration of $\mathrm{Cd}, \mathrm{Pb}$ and $\mathrm{Zn}$ was found in the leaves of $V$. myrtillus (Table 6).

Guaiacol peroxidase activity was by far the highest in the leaves of $V$. myrtillus from the L2 site (5.43-9.60 $\mu \mathrm{mol}$ tetraguaiacol $\mathrm{g}^{1}$ fresh weight $\mathrm{min}^{-1}$ ), where the leaves of bilberry had the highest concentration of iron (Fig. 5). Meanwhile, the lowest GPX activity was observed in July and September at M1 (0.63-0.67 $\mu \mathrm{mol}$ tetra-guaiacol $\mathrm{g}^{-1}$ fresh weight $\min ^{-1}$; Fig. 5). Guaiacol peroxidase activity in leaves of bilberries was positively correlated with Fe content, and negatively with the concentration of $\mathrm{Cd}, \mathrm{Pb}$ and $\mathrm{Zn}$ (Table 6).

There were no significant differences in proline content between the contaminated and potentially non-contaminated sites (Fig. 6). There were also no significant correlations between proline content and the concentration of the examined metals in leaves of $V$. myrtillus (Table 6). PCA analysis

Table 2 The concentration of selected metals (milligrams per kilogram) in fractions of the soils extracted with $\mathrm{HNO}_{3}($ mean values $\pm \mathrm{SE}, n=5$ )

\begin{tabular}{llllllll}
\hline Element & Month site & M1 & L2 & J3 & P4 & PB5 & K6 \\
\hline Cd & May & $19.71 \pm 2.35 \mathrm{c}$ & $7.80 \pm 0.61 \mathrm{~b}$ & $8.79 \pm 0.16 \mathrm{~b}$ & $2.76 \pm 0.26 \mathrm{a}$ & $2.94 \pm 0.06 \mathrm{a}$ & $0.68 \pm 0.00 \mathrm{a}$ \\
& July & $13.72 \pm 0.17 \mathrm{e}$ & $4.76 \pm 0.20 \mathrm{~d}$ & $4.23 \pm 0.02 \mathrm{c}$ & $3.07 \pm 0.05 \mathrm{c}$ & $4.77 \pm 0.03 \mathrm{~d}$ & $0.45 \pm 0.02 \mathrm{a}$ \\
& September & $25.54 \pm 0.56 \mathrm{~d}$ & $4.22 \pm 0.20 \mathrm{~b}$ & $7.86 \pm 0.70 \mathrm{c}$ & $1.33 \pm 0.06 \mathrm{a}$ & $5.30 \pm 0.37 \mathrm{~b}$ & $0.85 \pm 0.03 \mathrm{a}$ \\
$\mathrm{Fe}$ & May & $931.40 \pm 65.50 \mathrm{a}$ & $2,321.90 \pm 107.00 \mathrm{~d}$ & $2,960.90 \pm 82.00 \mathrm{e}$ & $1,205.40 \pm 103.50 \mathrm{~b}$ & $3,428.40 \pm 2.50 \mathrm{f}$ & $1,577.40 \pm 33.50 \mathrm{c}$ \\
& July & $1,151.40 \pm 11.00 \mathrm{a}$ & $1,345.90 \pm 55.00 \mathrm{~b}$ & $1,947.90 \pm 25.00 \mathrm{e}$ & $1,208.40 \pm 11.50 \mathrm{a}$ & $1,652.40 \pm 6.50 \mathrm{~d}$ & $1,545.90 \pm 6.00 \mathrm{c}$ \\
& September & $1,460.40 \pm 59.50 \mathrm{~b}$ & $1,247.90 \pm 9.00 \mathrm{a}$ & $3,586.40 \pm 108.50 \mathrm{e}$ & $2,129.90 \pm 44.00 \mathrm{c}$ & $2,658.90 \pm 22.00 \mathrm{~d}$ & $2,560.40 \pm 10.50 \mathrm{~d}$ \\
$\mathrm{Mn}$ & May & $35.27 \pm 2.95 \mathrm{~b}$ & $194.30 \pm 13.90 \mathrm{~d}$ & $111.55 \pm 1.35 \mathrm{c}$ & $17.20 \pm 0.57 \mathrm{a}$ & $8.59 \pm 0.28 \mathrm{a}$ & $6.84 \pm 0.33 \mathrm{a}$ \\
& July & $49.96 \pm 0.54 \mathrm{~d}$ & $94.70 \pm 4.70 \mathrm{e}$ & $47.41 \pm 0.86 \mathrm{c}$ & $26.70 \pm 0.22 \mathrm{~b}$ & $7.53 \pm 0.06 \mathrm{a}$ & $3.73 \pm 0.09 \mathrm{a}$ \\
& September & $39.42 \pm 2.21 \mathrm{~b}$ & $71.35 \pm 1.35 \mathrm{c}$ & $120.85 \pm 7.95 \mathrm{~d}$ & $1.89 \pm 0.23 \mathrm{a}$ & $8.48 \pm 0.64 \mathrm{a}$ & $4.43 \pm 0.22 \mathrm{a}$ \\
$\mathrm{Pb}$ & May & $674.49 \pm 76.50 \mathrm{e}$ & $362.14 \pm 20.15 \mathrm{c}$ & $481.14 \pm 3.15 \mathrm{~d}$ & $224.54 \pm 19.85 \mathrm{ab}$ & $316.44 \pm 7.95 \mathrm{bc}$ & $175.84 \pm 40.25 \mathrm{a}$ \\
& July & $1,655.49 \pm 8.50 \mathrm{e}$ & $239.44 \pm 10.15 \mathrm{c}$ & $287.89 \pm 2.00 \mathrm{~d}$ & $253.64 \pm 3.05 \mathrm{c}$ & $182.59 \pm 0.50 \mathrm{~b}$ & $81.64 \pm 1.25 \mathrm{a}$ \\
& September & $1,874.99 \pm 45.00 \mathrm{e}$ & $235.19 \pm 6.90 \mathrm{bc}$ & $524.44 \pm 35.55 \mathrm{~d}$ & $174.74 \pm 8.15 \mathrm{ab}$ & $265.79 \pm 8.90 \mathrm{c}$ & $124.59 \pm 0.90 \mathrm{a}$ \\
$\mathrm{Zn}$ & May & $856.50 \pm 97.50 \mathrm{~d}$ & $559.50 \pm 39.50 \mathrm{c}$ & $486.85 \pm 11.35 \mathrm{c}$ & $144.90 \pm 13.30 \mathrm{~b}$ & $85.60 \pm 0.70 \mathrm{ab}$ & $19.17 \pm 0.43 \mathrm{a}$ \\
& July & $430.75 \pm 3.55 \mathrm{f}$ & $321.40 \pm 10.20 \mathrm{e}$ & $234.20 \pm 0.80 \mathrm{~d}$ & $149.80 \pm 2.20 \mathrm{c}$ & $76.80 \pm 0.10 \mathrm{~b}$ & $36.80 \pm 8.37 \mathrm{a}$ \\
& September & $871.50 \pm 2.50 \mathrm{e}$ & $260.65 \pm 12.35 \mathrm{c}$ & $479.80 \pm 33.20 \mathrm{~d}$ & $47.69 \pm 4.01 \mathrm{a}$ & $149.45 \pm 8.45 \mathrm{~b}$ & $54.55 \pm 3.05 \mathrm{~b}$ \\
\hline
\end{tabular}

The different letters denote significant differences between the particular metal concentrations in the same month $(p<0.05)$ 
Table 3 The concentration of selected metals (milligrams per kilogram) in fractions of the soils extracted with $\mathrm{CaCl}_{2}($ mean values $\pm \mathrm{SE}, n=5$ )

\begin{tabular}{llllllll}
\hline Element & Month site & M1 & L2 & J3 & P4 & PB5 & K6 \\
\hline $\mathrm{Cd}$ & May & $5.44 \pm 0.19 \mathrm{~d}$ & $0.36 \pm 0.00 \mathrm{ab}$ & $0.83 \pm 0.12 \mathrm{c}$ & $0.79 \pm 0.14 \mathrm{bc}$ & $0.82 \pm 0.10 \mathrm{c}$ & $0.18 \pm 0.04 \mathrm{a}$ \\
& July & $4.82 \pm 0.15 \mathrm{~d}$ & $0.20 \pm 0.00 \mathrm{a}$ & $0.51 \pm 0.01 \mathrm{~b}$ & $0.46 \pm 0.01 \mathrm{~b}$ & $1.34 \pm 0.01 \mathrm{c}$ & $0.16 \pm 0.01 \mathrm{a}$ \\
& September & $8.59 \pm 0.34 \mathrm{~d}$ & $0.50 \pm 0.02 \mathrm{ab}$ & $0.87 \pm 0.01 \mathrm{~b}$ & $0.58 \pm 0.01 \mathrm{ab}$ & $1.31 \pm 0.08 \mathrm{c}$ & $0.29 \pm 0.00 \mathrm{a}$ \\
$\mathrm{Fe}$ & May & $1.79 \pm 0.01 \mathrm{a}$ & $1.66 \pm 0.07 \mathrm{a}$ & $14.51 \pm 11.34 \mathrm{ab}$ & $26.48 \pm 0.42 \mathrm{~b}$ & $61.90 \pm 7.45 \mathrm{c}$ & $24.31 \pm 5.05 \mathrm{~b}$ \\
& July & $1.84 \pm 0.02 \mathrm{~b}$ & $1.18 \pm 0.02 \mathrm{a}$ & $3.60 \pm 0.17 \mathrm{c}$ & $4.31 \pm 0.07 \mathrm{~d}$ & $22.62 \pm 0.24 \mathrm{e}$ & $35.68 \pm 0.32 \mathrm{f}$ \\
& September & $14.25 \pm 10.44 \mathrm{~b}$ & $1.02 \pm 0.01 \mathrm{a}$ & $6.91 \pm 0.42 \mathrm{ab}$ & $41.30 \pm 2.45 \mathrm{c}$ & $46.80 \pm 1.25 \mathrm{c}$ & $48.10 \pm 0.75 \mathrm{c}$ \\
$\mathrm{Mn}$ & May & $10.82 \pm 0.65 \mathrm{a}$ & $10.65 \pm 0.38 \mathrm{a}$ & $12.68 \pm 6.79 \mathrm{a}$ & $7.91 \pm 0.13 \mathrm{a}$ & $9.67 \pm 1.49 \mathrm{a}$ & $6.24 \pm 1.37 \mathrm{a}$ \\
& July & $14.17 \pm 0.87 \mathrm{~b}$ & $3.54 \pm 0.02 \mathrm{a}$ & $4.25 \pm 0.11 \mathrm{a}$ & $3.94 \pm 0.03 \mathrm{a}$ & $12.86 \pm 7.52 \mathrm{~b}$ & $2.74 \pm 0.11 \mathrm{a}$ \\
& September & $24.54 \pm 0.32 \mathrm{c}$ & $6.99 \pm 0.31 \mathrm{~b}$ & $24.89 \pm 1.18 \mathrm{c}$ & $2.32 \pm 0.01 \mathrm{a}$ & $6.69 \pm 0.09 \mathrm{a}$ & $3.06 \pm 0.52 \mathrm{a}$ \\
$\mathrm{Pb}$ & May & $3.36 \pm 2.61 \mathrm{a}$ & $1.14 \pm 0.11 \mathrm{a}$ & $6.74 \pm 2.19 \mathrm{~b}$ & $4.53 \pm 0.07 \mathrm{a}$ & $2.72 \pm 0.01 \mathrm{a}$ & $1.75 \pm 0.74 \mathrm{a}$ \\
& July & $37.20 \pm 0.75 \mathrm{~d}$ & $0.96 \pm 0.06 \mathrm{a}$ & $8.97 \pm 0.10 \mathrm{c}$ & $2.63 \pm 0.27 \mathrm{a}$ & $2.82 \pm 0.08 \mathrm{~b}$ & $1.56 \pm 0.18 \mathrm{a}$ \\
& September & $22.29 \pm 1.80 \mathrm{c}$ & $1.24 \pm 0.49 \mathrm{a}$ & $3.43 \pm 0.54 \mathrm{a}$ & $8.46 \pm 0.10 \mathrm{~b}$ & $3.50 \pm 0.04 \mathrm{a}$ & $1.86 \pm 0.64 \mathrm{a}$ \\
$\mathrm{Zn}$ & May & $341.00 \pm 13.50 \mathrm{c}$ & $37.18 \pm 0.57 \mathrm{ab}$ & $72.10 \pm 29.35 \mathrm{~b}$ & $60.63 \pm 8.32 \mathrm{~b}$ & $35.73 \pm 4.33 \mathrm{ab}$ & $10.28 \pm 1.68 \mathrm{a}$ \\
& July & $212.28 \pm 8.52 \mathrm{~d}$ & $21.60 \pm 0.44 \mathrm{~b}$ & $39.70 \pm 0.30 \mathrm{c}$ & $36.85 \pm 0.80 \mathrm{c}$ & $32.50 \pm 0.25 \mathrm{c}$ & $8.57 \pm 0.08 \mathrm{a}$ \\
& September & $477.75 \pm 0.25 \mathrm{f}$ & $49.00 \pm 2.50 \mathrm{c}$ & $83.35 \pm 0.45 \mathrm{e}$ & $30.35 \pm 0.35 \mathrm{~b}$ & $73.93 \pm 1.98 \mathrm{~d}$ & $20.75 \pm 0.10 \mathrm{a}$
\end{tabular}

The different letters denote significant differences between the particular metal concentrations in the same month $(p<0.05)$

confirmed a strong correlation between the concentration of $\mathrm{Cd}, \mathrm{Pb}$ and $\mathrm{Zn}$, and the content of non-protein -SH groups and protein. It also showed a strong link between NPTs and total glutathione content. These relationships are best reflected in the most polluted area (M1). The analysis also demonstrated the close correlation between the activity of GPX and Fe content in leaves of $V$. myrtillus at the L2 site (Fig. 7).

\section{Discussion}

The prediction of bioavailability of metals is of crucial importance for the assessment of environmental quality of contaminated soil (Gupta and Sinha 2007). The distribution and abundance of total metal concentrations are useful indicators of the extent of soil contamination (Tokalioglu et al. 2000; Xiao et al. 2011; Dao et al. 2012), but risk from

Table 4 The concentrations of heavy metals (milligrams per kilogram dry weight) in the leaves of $V$. myrtillus (mean values \pm SE, $n=5$ )

\begin{tabular}{|c|c|c|c|c|c|c|c|c|c|}
\hline Element & $\begin{array}{l}\text { Site } \\
\text { month }\end{array}$ & M1 & L2 & $\mathrm{J} 3$ & P4 & PB5 & K6 & $\begin{array}{l}\text { Sufficient } \\
\text { or normal }^{\mathrm{a}}\end{array}$ & $\begin{array}{l}\text { Excessive } \\
\text { or toxic }^{a}\end{array}$ \\
\hline \multirow[t]{3}{*}{$\mathrm{Cd}$} & May & $1.21 \pm 0.13 \mathrm{c}$ & $0.86 \pm 0.09 \mathrm{~b}$ & nd & $0.34 \pm 0.02 \mathrm{a}$ & nd & nd & & \\
\hline & July & $1.63 \pm 0.11 \mathrm{c}$ & $0.86 \pm 0.09 \mathrm{~b}$ & nd & $0.41 \pm 0.01 \mathrm{a}$ & nd & nd & $0.05-0.2$ & $5-30$ \\
\hline & September & $6.26 \pm 0.22 \mathrm{~d}$ & $0.88 \pm 0.07 \mathrm{c}$ & nd & $0.44 \pm 0.01 \mathrm{~b}$ & $0.98 \pm 0.14 \mathrm{c}$ & $0.09 \pm 0.07 \mathrm{a}$ & & \\
\hline \multirow[t]{3}{*}{$\mathrm{Fe}$} & May & $68.00 \pm 0.48 \mathrm{e}$ & $127.75 \pm 2.00 \mathrm{f}$ & $53.45 \pm 0.83 \mathrm{~d}$ & $50.54 \pm 0.52 \mathrm{c}$ & $14.73 \pm 0.07 \mathrm{~b}$ & $9.36 \pm 0.00 \mathrm{a}$ & & \\
\hline & July & $68.97 \pm 0.00 \mathrm{c}$ & $164.29 \pm 0.00 \mathrm{e}$ & $52.95 \pm 2.70 \mathrm{~b}$ & $13.52 \pm 9.50 \mathrm{a}$ & $90.25 \pm 8.67 \mathrm{~d}$ & $71.74 \pm 2.38 \mathrm{c}$ & - & - \\
\hline & September & $118.24 \pm 1.15 \mathrm{~d}$ & $409.49 \pm 6.33 \mathrm{f}$ & $50.94 \pm 0.65 \mathrm{~b}$ & $90.17 \pm 16.48 \mathrm{c}$ & $240.15 \pm 9.00 \mathrm{e}$ & $11.26 \pm 2.21 \mathrm{a}$ & & \\
\hline \multirow[t]{3}{*}{$\mathrm{Mn}$} & May & $38.82 \pm 1.03 \mathrm{a}$ & $74.81 \pm 2.52 \mathrm{~b}$ & $182.49 \pm 1.50 \mathrm{c}$ & $282.99 \pm 9.00 \mathrm{e}$ & $267.16 \pm 0.17 \mathrm{~d}$ & $257.66 \pm 10.00 \mathrm{~d}$ & & \\
\hline & July & $45.99 \pm 1.93 \mathrm{a}$ & $97.84 \pm 0.68 \mathrm{a}$ & $280.82 \pm 28.50 \mathrm{~b}$ & $460.49 \pm 71.83 \mathrm{c}$ & $1,138.99 \pm 103.67 \mathrm{e}$ & $917.66 \pm 1.33 \mathrm{~d}$ & $30-300$ & $\begin{array}{l}400- \\
1,000\end{array}$ \\
\hline & September & $45.99 \pm 3.77 \mathrm{a}$ & $99.47 \pm 3.82 \mathrm{a}$ & $397.99 \pm 1.33 \mathrm{~b}$ & $600.99 \pm 14.33 \mathrm{c}$ & $1,056.16 \pm 69.83 \mathrm{~d}$ & $610.82 \pm 145.50 \mathrm{c}$ & & \\
\hline \multirow[t]{3}{*}{$\mathrm{Pb}$} & May & $35.88 \pm 6.08 \mathrm{~b}$ & $13.44 \pm 1.43 \mathrm{a}$ & $10.97 \pm 6.96 \mathrm{a}$ & $3.56 \pm 0.35 \mathrm{a}$ & $9.39 \pm 0.94 \mathrm{a}$ & $9.39 \pm 2.42 \mathrm{a}$ & & \\
\hline & July & $54.94 \pm 3.32 \mathrm{c}$ & $7.56 \pm 0.59 \mathrm{a}$ & $8.77 \pm 0.81 \mathrm{a}$ & $10.40 \pm 3.09 \mathrm{a}$ & $23.83 \pm 3.70 \mathrm{~b}$ & $14.39 \pm 2.58 \mathrm{a}$ & $5-10$ & $30-300$ \\
\hline & September & $157.09 \pm 2.13 \mathrm{~d}$ & $8.80 \pm 0.15 \mathrm{a}$ & $7.76 \pm 1.58 \mathrm{a}$ & $6.92 \pm 0.74 \mathrm{a}$ & $40.13 \pm 0.83 \mathrm{c}$ & $14.92 \pm 1.68 \mathrm{~b}$ & & \\
\hline \multirow[t]{3}{*}{$\mathrm{Zn}$} & May & $69.73 \pm 0.63 \mathrm{f}$ & $19.82 \pm 0.45 \mathrm{~d}$ & $13.48 \pm 0.48 \mathrm{~b}$ & $17.92 \pm 0.42 \mathrm{c}$ & $26.85 \pm 0.12 \mathrm{e}$ & $11.21 \pm 0.63 \mathrm{e}$ & & \\
\hline & July & $97.98 \pm 0.08 \mathrm{e}$ & $26.38 \pm 0.18 \mathrm{c}$ & $21.58 \pm 1.18 \mathrm{~b}$ & $35.53 \pm 0.13 \mathrm{~b}$ & $38.60 \pm 2.40 \mathrm{~d}$ & $17.08 \pm 0.15 \mathrm{a}$ & $27-150$ & $100-400$ \\
\hline & September & $207.17 \pm 5.50 \mathrm{~d}$ & $36.80 \pm 0.13 \mathrm{~b}$ & $17.90 \pm 0.27 \mathrm{a}$ & $21.12 \pm 1.75 \mathrm{a}$ & $72.32 \pm 0.25 \mathrm{c}$ & $20.78 \pm 4.29 \mathrm{a}$ & & \\
\hline
\end{tabular}

The different letters denote significant differences between the particular metal concentrations in the same month $(p<0.05)$

${ }^{\text {a }}$ According to Kabata-Pendias and Pendias 2001 
Table 5 The correlation coefficients between the concentrations of particular metals in separate soil extracants $\left(\right.$ with $\mathrm{HNO}_{3}$ or $\left.\mathrm{CaCl}_{2}\right)$ and in the leaves of V. myrtillus $(p<0.05)$

\begin{tabular}{|c|c|c|c|c|c|c|c|c|c|c|}
\hline & \multicolumn{2}{|l|}{$\mathrm{Cd}$} & \multicolumn{2}{|l|}{$\mathrm{Fe}$} & \multicolumn{2}{|l|}{$\mathrm{Mn}$} & \multicolumn{2}{|l|}{$\mathrm{Pb}$} & \multicolumn{2}{|l|}{$\mathrm{Zn}$} \\
\hline & $\mathrm{HNO}_{3}$ & $\mathrm{CaCl}_{2}$ & $\mathrm{HNO}_{3}$ & $\mathrm{CaCl}_{2}$ & $\mathrm{HNO}_{3}$ & $\mathrm{CaCl}_{2}$ & $\mathrm{HNO}_{3}$ & $\mathrm{CaCl}_{2}$ & $\mathrm{HNO}_{3}$ & $\mathrm{CaCl}_{2}$ \\
\hline Leaves of $V$. myrtillus & 0.81 & 0.86 & NS & NS & NS & NS & 0.85 & 0.61 & 0.62 & 0.89 \\
\hline
\end{tabular}

NS not significant

metals depends on their bioavailability (Prokop et al. 2003; van Gestel 2008; Dao et al. 2012). A large part of biomonitoring research consists in the comparison of bioavailable fractions of metals (extracted with $\mathrm{CaCl}$ ) with their total concentration or pseudo-total (extracted, e.g. $2 \mathrm{M} \mathrm{HNO} 3$ ) in soil (Ullrich et al. 1999; Peijenburg and Jager 2003; Pueyo et al. 2004; Keller and Hammer 2004). The assessment of the environmental risk requires the determination of not only total metal concentrations in soils but also the bioavailable fraction (Dao et al. 2012).

There was a clear difference between the concentration of the studied metals in the potentially bioavailable extracted fraction of $\mathrm{CaCl}_{2}$, and $\mathrm{HNO}_{3}$ extracted fraction at all the studied sites (Tables 2 and 3). Some differences in the metal concentration sequences in the examined soil extracts and leaves of $V$. myrtillus were found. The order of metals in the soil fraction extracted with $\mathrm{HNO}_{3}$ was as follows: $\mathrm{Fe}>\mathrm{Pb}>$ $\mathrm{Zn}>\mathrm{Mn}>\mathrm{Cd}$, and for the $\mathrm{CaCl}_{2}$ extracts, it was $\mathrm{Mn}>\mathrm{Zn}>$ $\mathrm{Cd}>\mathrm{Pb}>\mathrm{Fe}$, while the range of metal contamination in the leaves was in the following order: $\mathrm{Mn}>\mathrm{Fe}>\mathrm{Zn}>\mathrm{Pb}>\mathrm{Cd}$.

A similar trend was observed by Celik et al. (2005) in Robinia pseudoacacia $(\mathrm{Fe}>\mathrm{Mn}>\mathrm{Zn}>\mathrm{Pb}>\mathrm{Cu}>\mathrm{Cd})$, Kafel et al. (2010) in the leaves of Philadelphus coronarius $(\mathrm{Zn}>\mathrm{Ni}$ $>\mathrm{Pb}>\mathrm{Cu}>\mathrm{Cd}$ ) and Kozanecka et al. (2002) in different plant species from the non-polluted areas of eastern Poland ( $\mathrm{Zn}>$ $\mathrm{Cu}>\mathrm{Ni}>\mathrm{Pb}>\mathrm{Cr}>\mathrm{Cd}$ ). An increase of $\mathrm{Cd}, \mathrm{Pb}$ and $\mathrm{Zn}$ in the leaves of $V$. myrtillus was strongly associated with the increased concentrations of these metals in both studied soil fractions (Table 5). A significantly higher level of $\mathrm{Cd}, \mathrm{Pb}$ and $\mathrm{Zn}$ was found in the leaves of $V$. myrtillus collected at the site located near the zinc smelter (M1) in comparison with other potentially contaminated areas and those free of contamination (Table 4). Levels of these three metals exceeded values considered as normal, and at the end of the growing season, in September, the levels exceeded values considered toxic for plants (according to Kabata-Pendias and Pendias 2001). Higher content of $\mathrm{Zn}\left(298 \mathrm{mg} \mathrm{kg}^{-1}\right)$, but lower $\mathrm{Pb}\left(8.93 \mathrm{mgkg}^{-1}\right)$ and $\mathrm{Cd}\left(3.20 \mathrm{mgkg}^{-1}\right)$ than in the presented study were found in the leaves of bilberries by Białońska et al. (2007) near the $\mathrm{Zn}-\mathrm{Pb}$ smelter in Bukowno. The concentration of Mn (Table 4) in the leaves of $V$. myrtillus at sites classified as unpolluted (P4, PB5 and K6) in most cases exceeded values considered as toxic to plants (according to Kabata-Pendias and Pendias 2001).

The ericaceous species, especially $V$. myrtillus, are distinguished by a high element content of $\mathrm{Mn}$, irrespective of the content in the soil (Reimann et al. 2001; Salemaa et al. 2004; Mróz and Demczuk 2010). Mróz and Demczuk (2010) suggested that $V$. myrtillus is an accumulator of $\mathrm{Mn}$, and such high concentrations of this element suggest a possibility that bilberry uses $\mathrm{Mn}$ for some beneficial purposes. At the other sites, the concentration of $\mathrm{Cd}, \mathrm{Pb}$, $\mathrm{Zn}, \mathrm{Fe}$ and $\mathrm{Mn}$ was similar to other uncontaminated sites reported in the literature (Reimann et al. 2001; Kozanecka et
Fig. 2 Total glutathione contents (micromoles GSHt per gram fresh weight) in $V$. myrtillus leaves (mean values \pm SE, $n=5$ ). Different letters above the columns indicate significant differences in the same month $(p<0.05)$

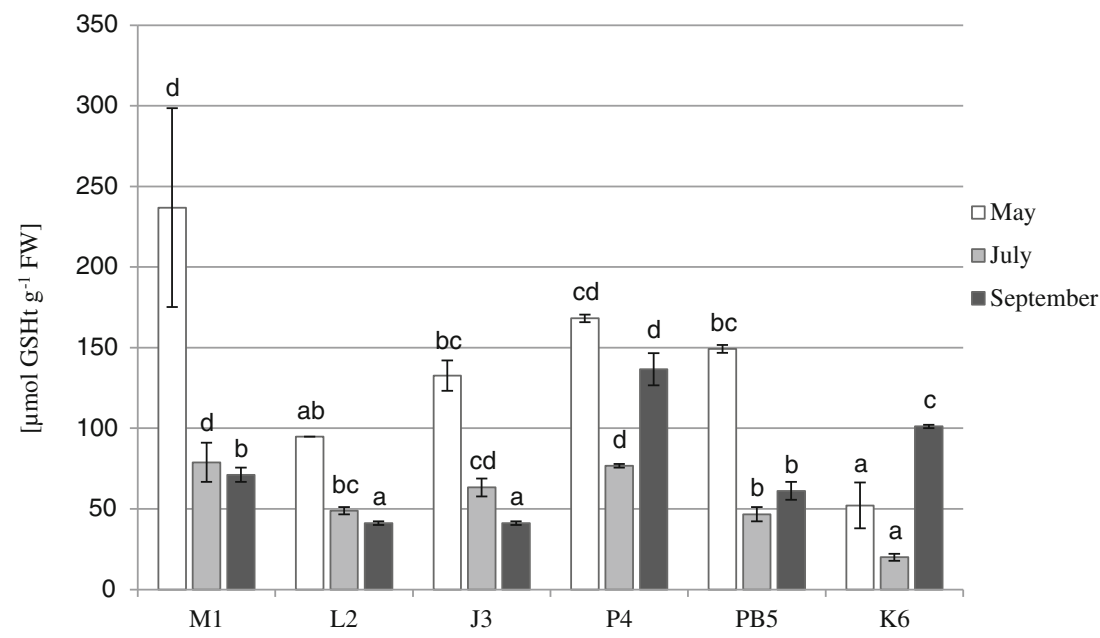


Table 6 The correlation coefficients between metal concentration and antioxidant measurements in the leaves of $V$. myrtillus $(p<0.05)$

\begin{tabular}{rclllc}
\hline & $\mathrm{Cd}$ & $\mathrm{Fe}$ & $\mathrm{Mn}$ & $\mathrm{Pb}$ & $\mathrm{Zn}$ \\
\hline GSHt & $\mathrm{NS}$ & -0.30 & -0.33 & $\mathrm{NS}$ & $\mathrm{NS}$ \\
NPTs & 0.31 & $\mathrm{NS}$ & $\mathrm{NS}$ & 0.38 & 0.40 \\
Protein & 0.66 & $\mathrm{NS}$ & $\mathrm{NS}$ & 0.64 & 0.65 \\
GPX & -0.29 & 0.30 & $\mathrm{NS}$ & -0.36 & -0.37 \\
Proline & $\mathrm{NS}$ & $\mathrm{NS}$ & $\mathrm{NS}$ & $\mathrm{NS}$ & $\mathrm{NS}$ \\
\hline
\end{tabular}

$N S$ not significant

al. 2002; Brekken and Steinnes 2004; Salemaa et al. 2004). In most cases, there was an increase in heavy metal accumulation in the leaves of $V$. myrtillus with each subsequent month when samples were collected.

Enzymatic antioxidant and non-enzymatic are important in heavy metals' plants defense (Gill and Tuteja 2010). A variation in the level of antioxidants was also noticed. Plants from polluted and unpolluted sites varied in glutathione total and proline content, $-\mathrm{SH}$ groups contents and the level of GPX activity.

Glutathione is the most important low molecular weight biological thiol and is crucial for detoxification of heavy metals (Yadav 2010). In our study, we found GSHt decline due to increased concentrations of Fe and Mn (Table 6). In many cases, exposure to heavy metals initially resulted in a severe depletion of glutathione ( $\mathrm{Cu}$ or $\mathrm{Cd}$ at ArabidopsisXiang and Oliver 1998; $\mathrm{Ni}$ and $\mathrm{Zn}$ at Cajanus cajanMadhava Rao and Sresty 2000; Cd at pine-Schützendübel et al. 2001; Pb at Raphanus sativus-El-Beltagi and Mohamed 2010; Pb at Vicia faba and Phaseolus vulgarisPiechalak et al. 2002). The decline in the glutathione content of plants may result from the inhibition of the enzymes involved in glutathione synthesis by toxic metal ions. In addition, the depletion of glutathione pool may also be considered to play some role in the synthesis of phytochelatins (Madhava Rao and Sresty 2000). Sudhakar et al. (2006) showed that exposure of Hydrilla verticillata (L.f) Royle to high doses of copper led to a decrease in GSH and an elevation in PC levels. Boojar and Tavakoli (2010) found a similar dependency in Alhagi camemelorum Fisch.

Tolerance toward metals correlates well with the level of non-protein thiols which include not only glutathione but also thiol-rich peptides known as phytochelatins and other SH-rich compounds (Kafel et al. 2010). Molecules containing sulphur, which exist in a wide variety in cells, may fulfill different functions and may be independently regulated (Mishra et al. 2009). In our study, an increase of the NPT content was noticed in the leaves of $V$. myrtillus grown at a polluted site (Fig. 3). Additionally, the content of nonprotein thiols was positively related with concentrations of $\mathrm{Cd}, \mathrm{Pb}$ and $\mathrm{Zn}$ (Table 6 and Fig. 7). This was similar to the study of Nadgórska-Socha et al. (2011) who observed an increase in non-protein - $\mathrm{SH}$ group content in leaves of Silene vulgaris populations on the substrate with $\mathrm{Cd}$ and combination of metals ( $\mathrm{Zn}, \mathrm{Cd}$ and $\mathrm{Pb}$ ). Also, Mishra et al. (2009) found a strong positive correlation between NPTs and $\mathrm{Cd}$ content in plants of Ceratophyllum demersum L. The increase in non-protein thiols levels indicates an ability to tolerate the cellular metal load (Mishra et al. 2006).

One of the mechanisms affected by heavy metals in plants is protein synthesis. It is known that soluble protein content is an important indicator of physiological status of plants (Doganlar and Atmaca 2011). In this study, we noticed a significant increase in protein content of bilberry leaves from most polluted site (Fig. 4), and we found a strong positive correlation between protein content and $\mathrm{Cd}$, $\mathrm{Pb}$ and $\mathrm{Zn}$ concentrations (Table 6 and Fig. 7). Similarly, Doganlar and Atmaca (2011) reported that an increase in total soluble protein contents related to $\mathrm{Al}$ concentration in leaves of Platanus orientalis and Zn concentration in leaves of Melia azaderach. Mesmar and Jaber (1991) found increased total protein with increasing lead concentration in wheat and lentil, and Singh et al. (2006) reported increased protein contents in Oryza sativa plants under Cd stress. The increase in protein
Fig. 3 Non-protein -SH groups content (nanomoles $-\mathrm{SH}$ per gram fresh weight) in $V$. myrtillus leaves (mean values \pm SE, $n=5)$. Different letters above the columns indicate significant differences in the same month $(p<0.05)$

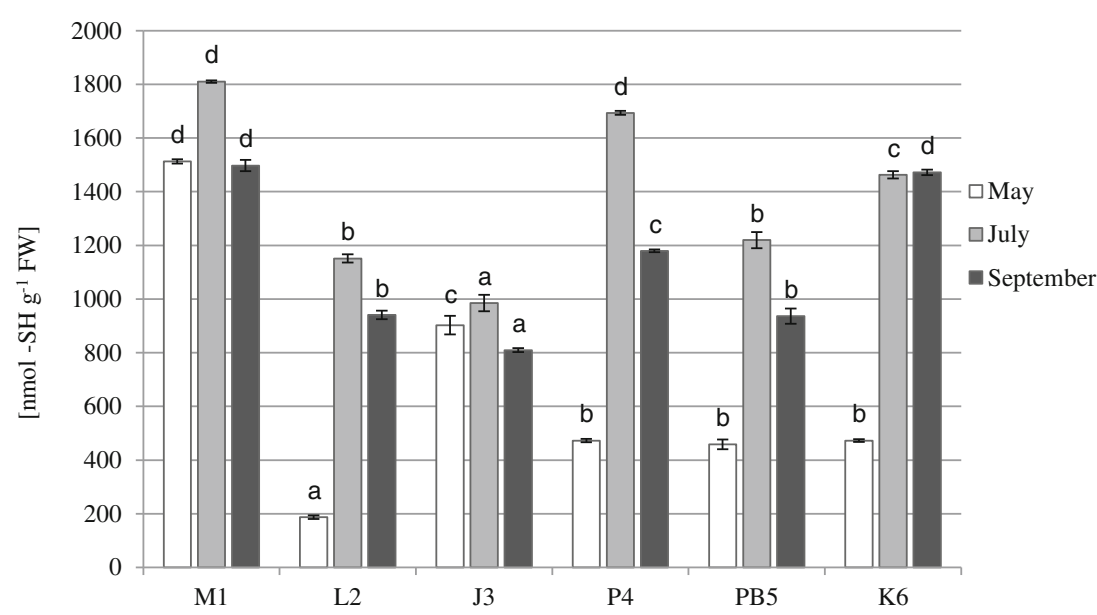


Fig. 4 Protein contents (milligrams per gram fresh weight) in $V$. myrtillus leaves (mean values $\pm \mathrm{SE}, n=5$ ). Different letters above the columns indicate significant differences in the same month $(p<0.05)$

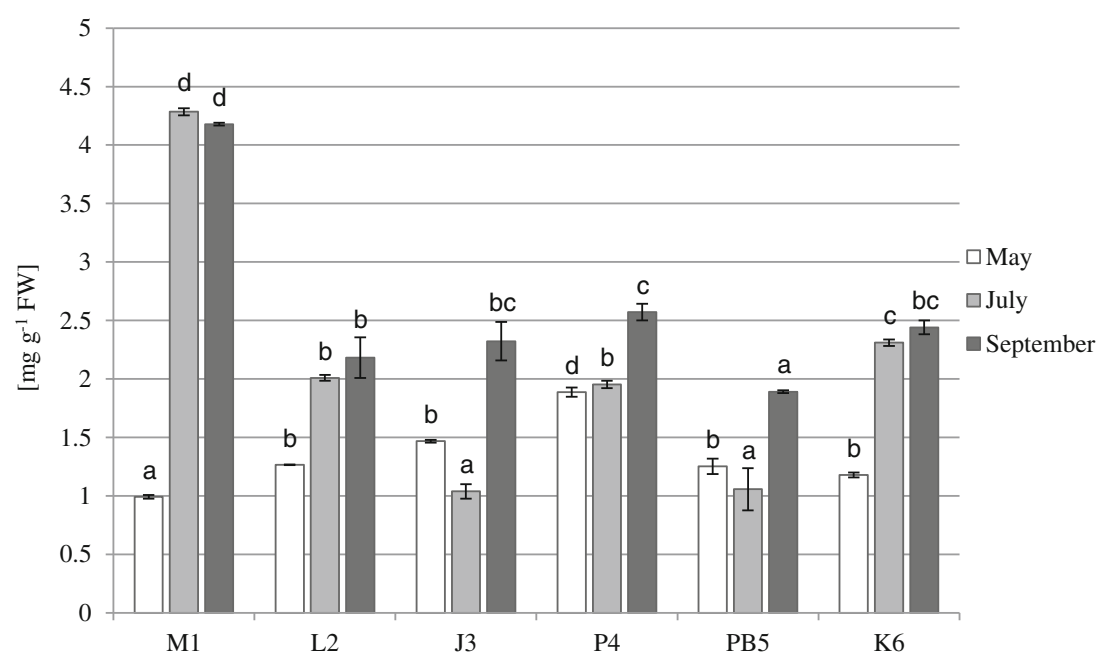

content may be a specific mechanism thanks to which cells compensate for the protein content that have been deactivated due to metal binding, and also the effect of the increasing the content of stress proteins (Mesmar and Jaber 1991; Seregin and Ivanov 2001).

Peroxidases are antioxidant enzymes which play a crucial role in plant growth and development, and activities of these enzymes are charged under both abiotic and abiotic stress conditions (Doganlar and Atmaca 2011). In this study, in the leaves of $V$. myrtillus the highest GPX activity was observed in the vicinity of iron smelter at the L2 site. The lowest values of guaiacol peroxidase activity were at M1 (Fig. 5). An increase in GPX activity in leaves of $V$. myrtillus was observed under the influence of $\mathrm{Fe}$ and its reduction in the presence of $\mathrm{Cd}, \mathrm{Pb}$ and $\mathrm{Zn}$ (Table 6 and Fig. 7). Many authors reported increased GPX activity increased content of heavy metals (Macfarlane and Burchett 2001; Markkola et al. 2002; Hagemeyer 2004; Kafel et al. 2010; El-Beltagi and Mohamed 2010; Doganlar and Atmaca 2011). The positive relationship between metal content and GPX activity was also reported by Nadgórska-Socha et al. (2008) in the leaves of Philadelphus coronarius Linne from a highly urbanized area of Krakow. However, Baycu et al. (2006), in their examination of peroxidase activity in leaves of Acer and Alianthus growing in the urban parks of Turkey, observed both increased and decreased peroxidase activity compared to controls. Pongrac et al. (2009) reported no change in GPX activity in Thlaspi praecox and Thlaspi caerulescens in the presence of $\mathrm{Cd}$ and $\mathrm{Zn}$; similar results were obtained by Gratão et al. (2008) in leaves, roots and fruits of tomato grown in conditions of cadmium contamination. Similar to our work, Sandalio et al. (2001) observed a decrease in peroxidase activity and other antioxidant enzymes in pea under the influence of Cd. Similar to the work of Stobrawa and Lorenc-Plucińska (2007), at most sites GPX activity was the highest in spring. Perhaps this is connected with the fact that peroxidases, while controlling the level of hydrogen peroxide, at the same time catalyze the synthesis of lignin-phenol polymers, a process that is most intense after the winter rest, i.e. in spring (Stobrawa and Lorenc-Plucińska 2007).

Accumulation of free proline in response to the impact of heavy metals is a widespread phenomenon among many plant species (Schat et al. 1997, Chen et al. 2004, Tripathi
Fig. 5 Guaiacol peroxidase activity (micromoles tetraguaiacol per gram fresh weight per minute) in $V$. myrtillus leaves (mean values $\pm \mathrm{SE}, n=5$ ). Different letters above the columns indicate significant differences in the same month $(p<$ 0.05)

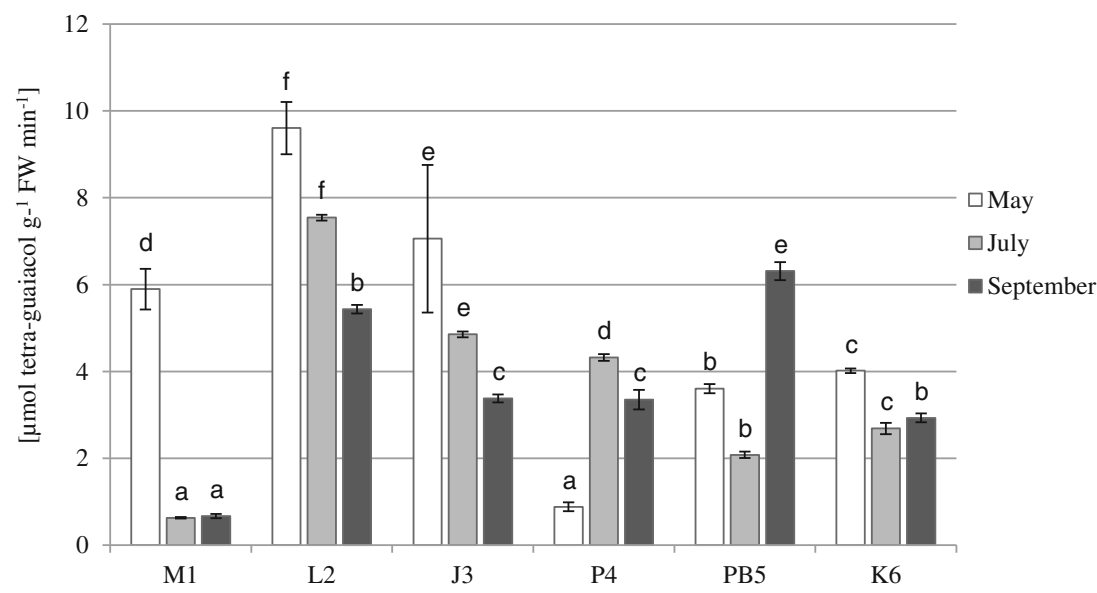


Fig. 6 Proline contents (mircomoles per gram fresh weight) in $V$. myrtillus leaves (mean values \pm SE, $n=5$ ).

Different letters above the columns indicate significant differences in the same month $(p<0.05)$

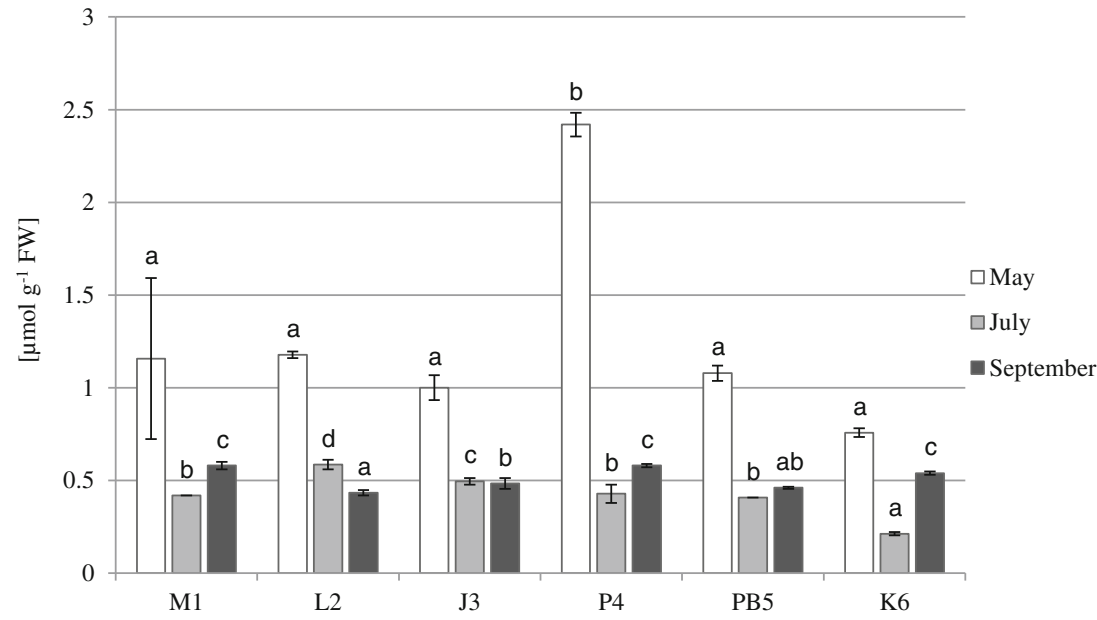

and Gaur 2004; Balestrasse et al. 2005; Sharma and Dietz 2006; Abdel-Latif 2008). Numerous studies have shown that the content of free proline depends on plant species and varies between organs. Moreover, proline concentration depends on the type of metal and its concentration (Sharma and Dietz 2006; Abdel-Latif 2008). Nikolić et al. (2008) found a significantly higher accumulation of free proline in the roots than in leaves of hybrid poplar under the influence of cadmium. Sharma and Dietz (2006) reported an increase in free proline accumulation in response to increased accumulation of heavy metals in several plant species (Cajanus cajan, Vigna mung, Helianthus annus, Lemna minor, Triticum aestivum, Lactuca sativa, Silene vulgaris, $O$. sativa). However, our tests have not found any significant effect of heavy metals on the accumulation of proline in the leaves of $V$. myrtillus. Proline content in leaves of bilberries only slightly differed between the various research sites.

It is difficult to draw unambiguous, major conclusions from research carried out in the field conditions because such experiments can be affected by environmental factors.
Fig. 7 Principal component analysis (PCA) biplot of sampling sites and heavy metal concentrations and biochemical parameters in the leaves of $V$. myrtillus

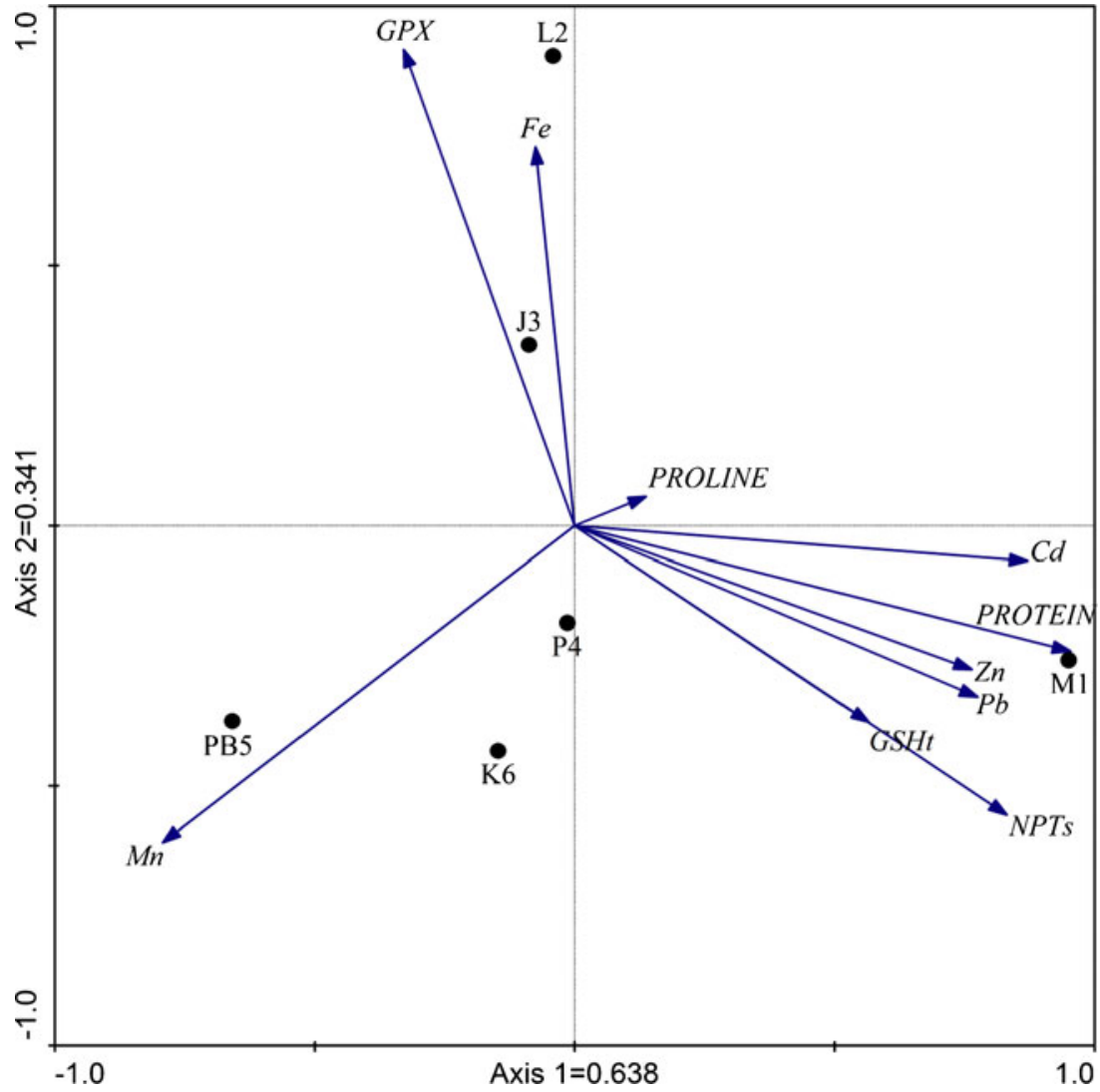


Nevertheless, multi-parameters approach provided understanding of the diverse responses and effects of exposure to contaminants, and the effective risk it poses for different plant species (Stobrawa and Lorenc-Plucińska 2007; Fonseca et al. 2011; Oliva et al. 2012).

Based on our study, we propose the following conclusions: An increase in content of protein and non-protein $\mathrm{SH}$ groups and changes in GPX activity in the leaves of $V$. myrtillus from polluted areas could be the evidence of an enhancement of the oxidative stress. Since these parameters seem to be universal, sensitive and correlated well with heavy metals stress, they could be good biochemical tools to predict heavy metal pollution.

Acknowledgments This work was financially supported by the Polish State Committee for Scientific Research, Project No. NN304 378938.

Open Access This article is distributed under the terms of the Creative Commons Attribution License which permits any use, distribution, and reproduction in any medium, provided the original author(s) and the source are credited.

\section{References}

Abdel-Latif A (2008) Cadmium induced changes in pigment content, ion uptake, proline content and phosphoenolpyruvate carboxylase activity in Triticum aestivum seedlings. Aust J Basic Appl Sci 2 (1):57-62

Anderson ME (1985) Determination of glutathione and glutathione disulfide in biological samples. Methods Enzymol 113:548-555

Andrade SAL, Gratão PL, Azevedo RA, Silveira APD, Schiavinato MA, Mazzafera P (2010) Biochemical and physiological changes in Jack bean under mycorrhizal symbiosis growing in soil with increasing $\mathrm{Cu}$ concentrations. Environ Exp Bot 68:198-207

Andrade SAL, Gratão PL, Schiavinato MA, Silveira APD, Azvedo RA, Mazzafera P (2009) Zn uptake, physiological response and stress attenuation in mycorrhizal jack bean growing in soil with increasing $\mathrm{Zn}$ concentrations. Chemosphere 75:1363-1370

Arya SK, Khalique S, Roy BK (2008) Glutathione and cysteine biosynthesis in two varieties of Abelmoschus esculentus in response to mine spoil. J Environ Biol 29(1):93-99

Balestrasse KB, Gallego SM, Benavides MP, Tomaro ML (2005) Polyamines and proline are affected by cadmium stress in nodules and roots of soybean plants. Plant Soil 270:343-353

Bates L, Waldren R, Teare D (1973) Rapid determination of free proline for water-stress studies. Plant Soil 39:205-207

Baycu G, Tolunay D, Özden H, Guenenebakan S (2006) Ecophysiological and seasonal variations in $\mathrm{Cd}, \mathrm{Pb}, \mathrm{Zn}$ and $\mathrm{Ni}$ concentrations in the leaves of urban deciduous trees in Istanbul. Environ Pollut 143:545-554

Białońska D, Zobel A, Kuraś M, Tykarska T, Sawicka-Kapusta K (2007) Phenolic compounds and cell structure in bilberry leaves affected by emissions from a $\mathrm{Zn}-\mathrm{Pb}$ smelter. Water Air Soil Poll 181:123-133

Boojar MMA, Tavakoli Z (2010) Role of antioxidant enzyme responses and phytochelatins in tolerance strategies of Alhagi camelorum Fisch growing on copper mine. Acta Bot Croat 69(1):107-121

Bouwman L, Bloem J, Römkens P, Boon G, Vangronsveld J (2001) Beneficial effects of the growth of metal tolerant grass on biological and chemical parameters in copper- and zinc contaminated sandy soils. Minerva Biotech 13:19-26

Bradford M (1976) A rapid and sensitive method for the quantization of microgram quantities of protein utilizing the principle of protein dye binding. Anal Biochem 44:276-287

Brekken A, Steinnes E (2004) Seasonal concentrations of cadmium and zinc in native pasture plants: consequences for grazing animals. Sci Total Environ 326:181-195

Celik A, Kartal AA, Akdoğan A, Kaska Y (2005) Determining the heavy metal pollution in Denizli (Turkey) by using Robinio pseudo-acacia L. Environ Int 31:105-112

Chen CT, Chen TH, Lo KF, Chiu CHY (2004) Effects of proline on copper transport in rice seedlings under excess copper stress. Plant Sci 166(1):103-111

Dao L, Morrison L, Kiely G, Zhang Ch (2012) Spatial distribution of potentially bioavailable metals in surface soils of a contaminated sports ground in Galway, Ireland. Environ Geochem Health. doi:10.1007/s10653-012-9478-7

Dazy M, Jung V, Ferard JF, Masfaraud JF (2008) Ecological recovery of vegetation on a coke-factory soil: role of plant antioxidant enzymes and possible implications in site restoration. Chemosphere 74:57-63

Demirevska-Kepova K, Simova-Stoilova L, Stoyanova Z, Holzer R, Feller U (2004) Biochemical changes in barley plants after excessive supply of copper and manganese. Environ Exp Bot 52:253-266

Deram A, Denayer FO, Petit D, Van Haluwyn C (2006) Seasonal variations of cadmium and zinc in Arrhenatherum elatius, a perennial grass species from highly contaminated soils. Environ Pollut 140:62-70

Doğanlar Z, Atmaca M (2011) Influence of airborne pollution on Cd, Zn, $\mathrm{Pb}, \mathrm{Cu}$, and $\mathrm{Al}$ accumulation and physiological parameters of plant leaves in Antakya (Turkey). Water Air Soil Poll 214(1/4):509-523

El-Beltagi H, Mohamed AA (2010) Changes in nonprotein thiols, some antioxidant enzymes activity and ultrastructural alteration in radish plant (Raphanus sativus L) grown under lead toxicity. Not Bot Hort Agrobot Cluj 38(3):76-85

Fang WC, Kao C (2000) Enhanced peroxidase activity in rice leaves in response to excess iron, copper and zinc. Plant Sci 158:71-76

Fonseca VF, França S, Serafim A, Company R, Lopes B, Bebianno MJ, Cabral HM (2011) Multi-biomarker responses to estuarine habitat contamination in three fish species: Dicentrarchus labrax, Solea senegalensis and Pomatoschistus microps. Aquat Toxicol 102(3-4):216-227

Gill SS, Tuteja N (2010) Reactive oxygen species and antioxidant machinery in abiotic stress tolerance in crop plants. Plant Physiol Bioch 48:909-930

Gratão PL, Monteiro CC, Antunes AM, Peres LEP, Azevedo RA (2008) Acquired tolerance of tomato (Lycopersicon esculentum cv. Micro-Tom) plants to cadmium-induced stress. Annals Applied Biol 153:321-333

Gratão PL, Polle A, Lea PJ, Azevedo RA (2005) Making the life of heavy metal-stressed plants a little easier. Funct Plant Biol 32:481-494

Gupta A, Sinha S (2007) Assesment of single extraction methods for the prediction of bioavailability of metals to Brassica juncea L. Czern. (var. Vaibhav) grown on tannery waste contaminated soil. J Hazard Mater 149:144-150

Hagemeyer J (2004) Ecophysiology of plant growth under heavy metal stress. In: Prasad MNV (ed) Heavy metal stress in plants: from biomolecules to ecosystems, 2nd edn. Springer, Berlin, pp 201-222

Kabata-Pendias A, Pendias H (2001) Trace elements in soils and plants, 3rd edn. CRC Press, Boca Raton

Kafel A, Nadgórska-Socha A, Gospodarek J, Babczyńska A, Skowronek M, Kandziora M, Rozpendek K (2010) The effects of Aphis fabae infestation on the antioxidant response and heavy metal content in field grown Philadelphus coronarius plants. Sci Total Environ 408 (5):1111-1119 
Keller C, Hammer D (2004) Metal availability and soil toxicity after repeated croppings of Thlaspi caerulescens in metal contaminated soils. Environ Pollut 131:243-254

Kim ND, Fergusson JE (1994) Seasonal variations in the concentrations of cadmium, copper, lead and zinc in leaves of the horse chestnut (Aesculus hippocastanum L.). Environ Pollut 86:89-97

Kozanecka T, Chojnicki J, Kwasowski (2002) Content of heavy metals in plant from pollution-free regions. Polish J Environ Stud 11 (4):395-399

Kumar N, Pal M, Singh A, Kumar SaiRam R, Srivastava GH (2010) Exogenous proline alleviates oxidative stress vase life in rose (Rosa hybrida L.'Grand Gala'). Sci Hortic 127:79-85

Liu J, Xiong Z, Li T, Huang H (2004) Bioaccumulation and ecophysiological responses to copper stress in two populations of Rumex dentatus $\mathrm{L}$. from $\mathrm{Cu}$ contaminated and non-contaminated sites. Environ Exp Bot 52(1):43-51

Macfarlane GR, Burchett MD (2001) Photosynthetic pigments and peroxidase activity as indicators of heavy metal stress in the Grey Mangrove Avicennia marina (Forsk.) Veirh. Mar Pollut Bull 42:233-240

Madhava Rao KV, Sresty TVS (2000) Antioxidative parameters in the seedling of pigeonpea (Cajanus cajan L. Millspaugh) in response to $\mathrm{Zn}$ and Ni stresses. Plant Science 157:113-128

Markkola AM, Tarvainen O, Ahonen-Jonnarth U, Strömmer R (2002) Urban polluted soils induce elevated root peroxidase activity in Scots pine (Pinus sylvestris L.) seedlings. Environ Pollut 116:273-278

Martin M, Couphtrey P (1982) Biological monitoring of heavy metal pollution. Applied Sciences Publications, London

Martz F, Jaakola L, Julkunen-Tiitto R, Stark S (2010) Phenolic composition and antioxidant capacity of bilberry (Vaccinium myrtillus) leaves in Northern Europe following foliar development and along environmental gradients. J Chem Ecol 36:1017-1028

Mass F, De Kok L, Peters J, Kuiper PA (1987) Comparative study on the effects of $\mathrm{H}_{2} \mathrm{~S}$ and $\mathrm{SO}_{2}$ fumigation on the growth and accumulation of sulfate and sulfhydryl compounds in Trifolium pratense L., Glycine max Merr., Phaseolus vulgaris L. J Exp Bot 38:1459-1469

Mesmar MN, Jaber K (1991) The toxic effect of lead on seed germination, growth, chlorophyll and protein contents of wheat and lens. Acta Biol Hung 42(4):331-344

Mishra S, Srivastava S, Tripathi RD, Kumar R, Seth CS, Gupta DK (2006) Lead detoxification by coontail (Ceratophyllum demersum L.) involves induction of phytochelatins and antioxidant system in response to its accumulation. Chemosphere 65:1027-1039

Mishra S, Tripathi RD, Srivastava S, Dwivedi S, Trivedi PK, Dhankher OP, Khare A (2009) Thiol metabolism play significant role during cadmium detoxification by Ceratophyllum demersum L. Bioresou Technol 100:2155-2161

Mróz L, Demczuk M (2010) Contents of phenolics and chemical elements in bilberry (Vaccinium myrtillus L.) leaves from copper smelter area. Pol J Ecol 58(3):475-486

Nadgórska-Socha A, Kafel A, Gospodarek J (2008) Heavy metals in leaves and physiological of Philadelphus coronarus L. in urban and unpolluted areas. Scripra Facultatis Naturalium Univ Ostraviensis 186:278-284

Nadgórska-Socha A, Kandziora-Ciupa M, Ciepał R, Walasek K (2011) Effects of $\mathrm{Zn}, \mathrm{Cd}, \mathrm{Pb}$ on physiological response of Silene vulgaris plants from selected populations. Polish J Environ Stud 20 (3):599-604

Nadgórska-Socha A, Kafel A, Kandziora-Ciupa M, Gospodarek J, Zawisza-Raszka A (2012) Accumulation of heavy metals and antioxidant responses in Vicia faba plants grown on monometallic contaminated soil. Environ Sci Pollut Res. doi:10.1007/s11356-012-1191-7

Nikolić N, Kojić D, Pilipović A, Pajević S, Krstić B, Borišev M, Orlović S (2008) Responses of hybrid poplar to cadmium stress: photosynthetic characteristics, cadmium and proline accumulation, and antioxidant enzyme activity. Acta Biol Cracov Ser Bot 502:95-103
Oliva M, José Vicente J, Gravato C, Guilhermino L, Dolores GalindoRiaño M (2012) Oxidative stress biomarkers in Senegal sole, Solea senegalensis, to assess the impact of heavy metal pollution in a Huelva estuary (SW Spain): seasonal and spatial variation. Ecotoxicol Environ Saf 75(1):151-162

Ostrowska A, Gawliński S, Szczubiałka Z (1991) In: Method of analysis and estimate soil and plants property, Catalogue of the Environmental Protection Institute Warsaw pp 334-336 (in Polish)

Peijnenburg WJ, Jager T (2003) Monitoring approaches to assess bioaccessibility and bioavailability of metals: matrix issues. Ecotoxicol Environ Saf 56:63-77

Piechalak A, Tomaszewska B, Baralkiewicz D, Małecka A (2002) Accumulation and detoxification of lead ions in legumes. Phytochemistry 60:153-162

Pongrac P, Zhao FJ, Razinger J, Zrimec A, Regvar M (2009) Physiological responces to $\mathrm{Cd}$ and $\mathrm{Zn}$ in two $\mathrm{Cd} / \mathrm{Zn}$ hyperaccumulating Thlaspi species. Environ Exp Bot 66:479-486

Prasad MNV (1999) Heavy metal stress in plants: from biomolecules to ecosystems. Springer, Berlin

Prokop Z, Cupr P, Zlevorova-Zlamalikova V, Komarek J, Dusek L, Holoubek I (2003) Mobility, bioavailability, and toxic effects of cadmium in soil samples. Environ Res 91(2):119-126

Pueyo M, Lopez-Sanchez JF, Rauret G (2004) Assessment of $\mathrm{CaCl}_{2}$, $\mathrm{NaNO}_{3}$ and $\mathrm{NH}_{4} \mathrm{NO}_{3}$ extraction procedures for the study of $\mathrm{Cd}$, $\mathrm{Cu}, \mathrm{Pb}$ and $\mathrm{Zn}$ extractability in contaminated soils. Anal Chimica Acta 504:217-226

Radotić K, Ducić T, Mutavdžic D (2000) Changes in peroxidase activity and isoenzymes in spruce needles after exposure to different concentrations of cadmium. Environ Exp Bot 44:105-113

Reimann C, Koller F, Frengstad B, Kashulina G, Niskavaara H, Englmaier P (2001) Comparison of the element composition in several plant species and their substrate from a $1500000-\mathrm{km}^{2}$ area in Northern Europe. Sci Total Environ 278:87-112

Salemaa M, Derome J, Helmisaari H-S, Nieminen T, Vanha-Majamaa I (2004) Element accumulation in boreal bryophytes, lichens and vascular plants exposed to heavy metal and sulfur deposition in Finland. Sci Total Environ 324:141-160

Sandalio LM, Dalurzo HC, Gómez M, Romero-Puertas MC, Del Río LA (2001) Cadmium-induced changes in the growth and oxidative metabolism of pea plants. J Exp Bot 52(364):2115-2126

Schat H, Sharma S, Vooijs R (1997) Heavy metal-induced accumulation of free proline in metal tolerant and nontolerant ecotype of Silene vulgaris. Physiol Plantarum 101:477-482

Schützendübel A, Schwanz P, Teichmann T, Gross K, LangenfeldHeyser R, Godbold DL, Polle A (2001) Cadmium-induced changes in antioxidative systems, hydrogen peroxide content and differentiation in Scots Pine roots. Plant Physiol 127:887-892

Seregin I, Ivanov V (2001) Physiological aspects of cadmium and lead toxic effects on higher plants. Russ J Plant Physiol 48:523-544

Sharma SS, Dietz KJ (2006) The significance of amino acids and amino acid-derived molecules in plant responses and adaptation to heavy metal stress. J Exp Bot 57:711-726

Singh AK, Misra P, Tandon PK (2006) Phytotoxicity of chromium in paddy (Oryza sativa L.) plants. J Environ Biol 27(2):283-285

Stobrawa K, Lorenc-Plucińska G (2007) Changes in antioxidant enzyme activity in the fine roots of black poplar (Populus nigra L.) and cottonwood (Populus deltoides Bartr. Ex Marsch) in heavymetal-polluted environment. Plant Soil 298:57-68

Sudhakar S, Seema M, Rudra DT, Sanjay D, Dharmendra KG (2006) Coper-induced oxidative stress and responses of antioxidants and phytochelatins in Hydrilla verticillata (L.f.) Royle. Aquat Toxicol 80:405-415

Tokalioglu S, Kartal S, Elc L (2000) Determination of heavy metals and their speciation in lake sediments by flame atomic absorption spectrometry after a four-stage sequential extraction procedure. Anal Chim Acta 413(1-2):33-40 
Tripathi BN, Gaur JP (2004) Relationship between copper- and zincinduced oxidative stress and proline accumulation in Scenedesmus sp. Planta 219:397-404

Uhlig C, Junttila O (2001) Airborne heavy metal pollution and its effects on foliar elemental composition of Empetrum hermaphroditum and Vaccinium myrtillus in Sor-Varanger, northern Norway. Environ Pollut 114:461-469

Ullrich SM, Ramsey MH, Helios-Rybicka E (1999) Total and exchangeable concentrations of heavy metals in soils near Bytom, an area of $\mathrm{Pb} / \mathrm{Zn}$ mining and smelting in Upper Silesia, Poland. Appl Geochem 14:187-196

Unyayar S, Celik A, Cekic FO, Gozel A (2006) Cadmium-induced genotoxicity, cytotoxicity and lipid peroxidation in Allium sativum and Vicia faba. Mutagenesis 21:77-81 van Gestel CAM (2008) Physico-chemical and biological parameters determine metal bioavailability in soils. Sci Total Environ 406 (3):385-395

Xiang C, Oliver DJ (1998) Glutathione metabolic genes coordinately respond to heavy metals and jasmonic acid in Arabidopsis. Plant Cell 10:1539-1550

Xiao R, Bai JH, Wang QG, Gao HF, Huang LB, Liu XH (2011) Assessment of heavy metal contamination of wetland soils from a typical aquatic-terrestrial ecotone in Haihe River Basin, North China. CLEAN-Soil, Air Water 39(7):612618

Yadav SK (2010) Heavy metals toxicity in plants: an overview on the role of glutathione and phytochelatins in heavy metal stress tolerance of plants. South African J Bot 76:167-179 